\title{
Sedimentary Inputs and Morphology Characterization of the Bottom Agropastoral Lake of Nafoun (North Ivory Coast)
}

\section{Anzoumanan Kamagate ${ }^{*}$, Yao Blaise Koffi ${ }^{1}$, Kouassi Ernest Ahoussi ${ }^{1}$, Michel Amani Kouassi², Hermann Essan Ehui ${ }^{1}$, Kouassi Serge Aristide Yao ${ }^{1}$, Seydou Diallo ${ }^{3}$}

\footnotetext{
${ }^{1}$ Training and Research Unit for Earth Sciences and Mining Resources, Soil, Water and Geomaterials Laboratory, Université Félix Houphouët-Boigny, Abidjan, Ivory Coast

${ }^{2}$ Departments of Earth Sciences and Mineral Resources, Civil Engineering, Geosciences and Geographic Sciences Laboratory, Yamoussoukro, Ivory Coast

${ }^{3}$ Environmental Science and Management Training and Research Unit, Laboratory Geosciences and Environment, Université Nangui Abrogoua, Abidjan, Ivory Coast

Email: ^anzoakm@gmail.com, yaomonie@yahoo.fr, akouassiernest@gmail.com,michel.a_kouassi@yahoo.fr, hermannehui27@gmail.com, yyserge0@gmail.com, dialitho1@hotmail.fr
}

How to cite this paper: Kamagate, A., Koffi, Y.B., Ahoussi, K.E., Kouassi, M.A., Ehui, H.E., Yao, K.S.A. and Diallo, S. (2020) Sedimentary Inputs and Morphology Characterization of the Bottom Agropastoral Lake of Nafoun (North Ivory Coast). Journal of Water Resource and Protection, 12, 389-400.

https://doi.org/10.4236/jwarp.2020.125023

Received: March 7, 2020

Accepted: April 23, 2020

Published: April 26, 2020

Copyright $\odot 2020$ by author(s) and Scientific Research Publishing Inc. This work is licensed under the Creative Commons Attribution International License (CC BY 4.0).

http://creativecommons.org/licenses/by/4.0/

\begin{abstract}
A bathymetric and sedimentological analysis carried out respectively in July 2017 and April 2018 made it possible to characterize the sediments and the morphology of Lake Nafoun. The sediments of the lake consist of vases, fine to very coarse sands with average particle sizes ranging from 475.67 and 2111 $\mu \mathrm{m}$. There is a predominance of very coarse elements (43.50\%). The standard deviation of the lake sand is between 1.21 and 1.86 and is poorly classified. The skewness fluctuates between -0.06 and 0.41 . The sediments were deposited at the bottom of the lake due to a progressive decline in the flow of water that carried them. Moreover, this study made it possible to realize the first bathymetric chart of Lake Nafoun, 42 years after its impoundment in 1975.
\end{abstract}

\section{Keywords}

Sediments, Morphology, Nafoun Lake, Bathymetry

\section{Introduction}

In the north of Ivory Coast, the development of agriculture has faced significant water deficits. These constraints led the State to envisage palliative measures to store surface water [1]. Thus, in the 1970s, 300 dam lakes were built in rural areas of northern Ivory Coast for drinking water supply, agriculture and lives- 
tock [2]. A few decades later, there is a decrease in the number of these works.

In 2012, 275 hydro-agricultural and pastoral schemes were inventoried in northern Côte d'Ivoire [1]. These reservoirs, which represent major assets to support the country's development, are threatened by hydrological variations, pollution and siltation problems. Filling water reservoirs is due to agricultural activities, rapid and uncontrolled urbanization that intensify erosion and increase sediment production [3] [4]. Thus, eroded sediments accumulate in the lake reservoir and reduce their storage capacity [5] which leads to social problems such as conflicts between farmers and stockbreeders [6] [7].

In spite of the dangers inherent in filling reservoirs with the passage of time, no sedimentological and morphological studies have yet been undertaken on Lake Nafoun, the largest agropastoral dam in the Poro region put into water in 1975. [8] and [9] point out that the sedimentation of water reservoirs leading to the reduction of their life span is one of the most harmful consequences of water erosion. The management of lake ecosystems requires in-depth knowledge of hydrodynamic and sedimentary functioning in order to propose development scenarios adapted to the various constraints of the environment: maintenance of water quality, improvement of fish and aquatic organism habitat, protection of structures, development of recreational and ecotourism activities [10] [11] [12].

This article presents the first bathymetric map of Lake Nafoun, 42 years after being filled with water. It also presents the granulometric characteristics of the sands and their spatial distribution in the lake of Nafoun.

\section{Materials and Methods}

\subsection{Study Area}

The Nafoun water reservoir, which is the subject of this study, is located west of the Poro region in northern Côte d'Ivoire, between latitudes $9^{\circ} 22^{\prime} \mathrm{N}$ and $9^{\circ} 18^{\prime} \mathrm{N}$ and longitudes $6^{\circ} 18^{\prime} \mathrm{N}$ and $6^{\circ} 15^{\prime} \mathrm{N}$ (Figure 1) covers an area of 1500 ha. It is built on the Bou, tributary of the White Bandama River. The Nafoun lake basin belongs to the tropical Sudano-Sahelian regime whose rhythm of the seasons is regulated by the displacement of the Intertropical Front (FIT). The rainy season is unique and lasts 7 months. It is continuous and extends from April to October [13] [14]. The maximum rainfall is in August and September. The average annual rainfall of the region is estimated at about $1200 \mathrm{~mm}$. The vegetation of the basin is essentially savannah. These are grassy, shrubby or treed savannas gallery forests and open forests are also encountered. These formations cover respectively $10 \%, 30 \%, 2 \%$ and $10 \%$ of the landscape, the rest of which is occupied by bare soils and crops [15]. The large fauna is still present, but in small quantities and is mainly found in classified forests. Geologically, the Lake Nafoun basin is part of the history of the West African craton [16] [17] [18]. There are two major sets on the lithological level: the Birrimian formations (volcanic, volcano-sedimentary and sedimentary, metamorphosed deposited in intracratonic furrows) and the Eburnian, granitoids formations (granite massifs within which 


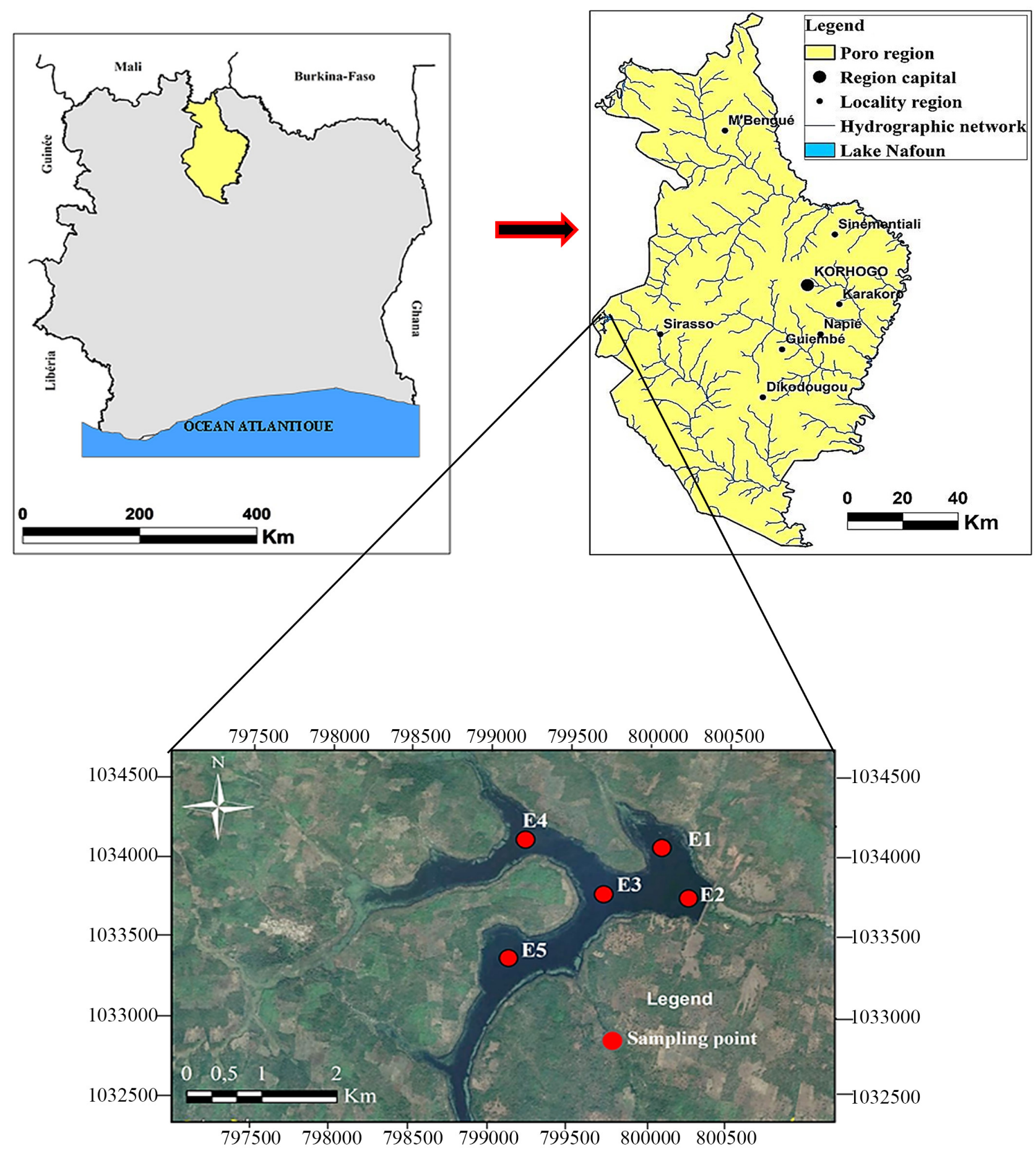

Figure 1. Location of the Nafoun reservoir.

several generations of granites and migmatites can be distinguished). Hydrogeologically, two types of aquifers are present: weathering reservoirs and crack reservoirs, which provide perennial water resources linked to the underground network of fractures very developed in these formations due to polyphase tectonics [13]. Overall, the relief of the Nafoun basin is flat and monotonous, but some peaks stand out, where the altitudes vary from 185 to $568 \mathrm{~m}$. 


\subsection{Method of Study}

To determine the granulometric characteristics of the sands of the Nafoun reservoir, 5 sediment samples were taken at depths between 4 and $1.5 \mathrm{~m}$ in the reservoir using a Van Veen grab and localized by a GPS-GARMIN. The Samples were taken during the wet season (April 2018). The sediments collected were subjected to a dry granulometric analysis according to the technique described by [19] (washing and separation of the fraction greater than $63 \mu \mathrm{m}$, drying in an oven at $105^{\circ} \mathrm{C}$, then sieving on a vibrating sifter surmounted by a column of 16 sieves of the AFNOR series of meshes between $5 \mathrm{~mm}$ and $63 \mu \mathrm{m}$ ). The sands of the Nafoun reservoir have been characterized according to three particle size distribution parameters, namely the mean particle size (Mz), the skewness (Sk) and the standard deviation or Sorting (So) determined using Folk methods (1957) [20]. The study of the morphology of the bottom of the Nafoun reservoir was carried out by means of bathymetric surveys (July, 2017), using a Lowrance type echo sounder model LMS-160. A total of 06 radials was drawn including one longitudinal and 05 transverse perpendicular to the flow directions. The bathymetric map of the Nafoun reservoir was made using the SURFER 11 software and the positioning maps were made using the Arc Gis 10.2.2 software.3.

\section{Results}

\subsection{Lithological Description of Sediments}

The macroscopic analysis of the superficial sediments of Lake Nafoun reveals three lithological facies. These are fine sands, medium sands and coarse sands. These facies result from alteration and disintegration of the parent rock and soils of the lake watersheds.

\subsection{Granulometric Sediment Analysis}

The semi-logarithmic cumulative curves of the lake sediments describe a logarithmic facies (Figure 2) which shows that the sediments were deposited by excess of charge after a progressive decrease of the energy of the water. The average values of the studied sand samples are between $475.67 \mu \mathrm{m}$ and $2111 \mu \mathrm{m}$ and indicate coarse to medium sands (Table 1). The size of the sand grains decreases going from the shallow depths ( 1 to $2 \mathrm{~m}$ ) to the highest ( 3 to $5 \mathrm{~m}$ ). The Skewness of superficial sediments ranged from -0.37 to 0.412 . The grain size curves of lake sediments show a strong asymmetry $(\mathrm{Sk}<0)$ towards coarse elements at shallow depths $(1-2 \mathrm{~m})$ and tend to become asymmetric (Sk $>0)$ towards fine elements from shallow depths towards the highest depths ( 3 to $5 \mathrm{~m}$ ). This shows the existence of granulometric sorting, [21] already observed in the sediments of Lake Nafoun, going from shallow banks to the channels.

\subsection{Classification of Lake Sediments}

The granulometric study of the sediment fraction greater than $63 \mu \mathrm{m}$ makes it possible to divide the sands of the lake. There are very coarse sands $(\phi \geq 1.25$ 


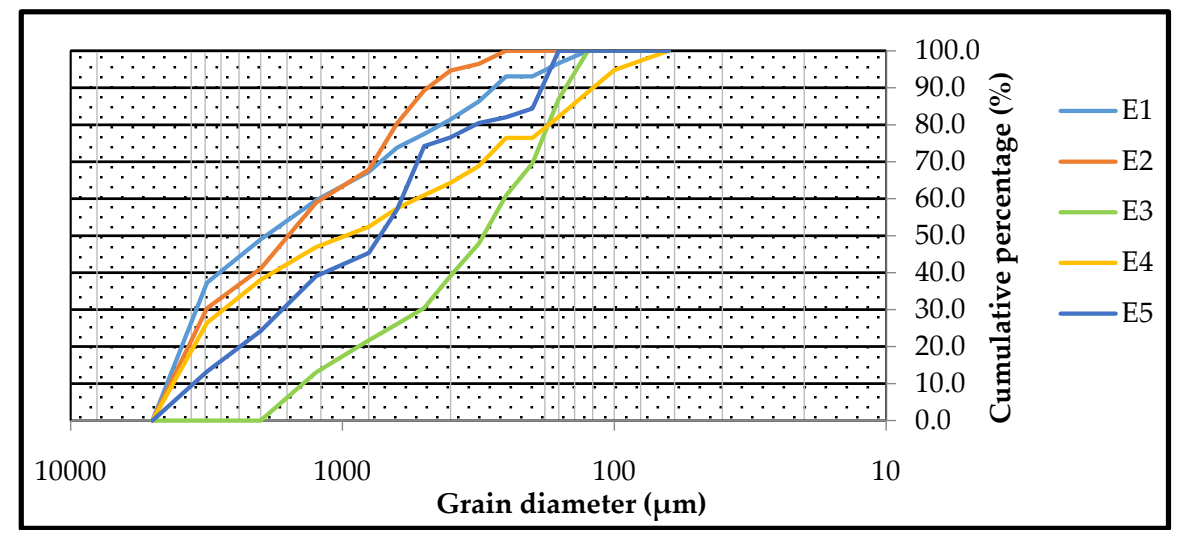

Figure 2. Particle size distribution curves of Nafoun lake sands.

Table 1. Granulometric characteristics of the sands of the Nafoun reservoir.

\begin{tabular}{cccccccccccccc}
\hline Samples & $\Phi 5$ & $\Phi 95$ & $\Phi 16$ & $\Phi 84$ & $\Phi 50$ & $\Phi 75$ & $\Phi 25$ & Mz en $\mu \mathrm{m}$ & So & Sk & Median & Mode \\
\hline e1 & -2.174 & 2.165 & -2.01 & 1.494 & -0.94 & -1.87 & 0.769 & 2111 & 1.535 & 0.412 & -0.947 & 3.15 \\
e2 & -2.159 & 1.385 & -1.96 & 0.793 & -0.7 & -1.77 & 0.508 & 2032.33 & 1.226 & 0.131 & -0.7 & 0.25 \\
e3 & -0.755 & 2.943 & 0.025 & 2.644 & 1.816 & 0.571 & 2.419 & 475.66 & 1.215 & -0.37 & 1.816 & 0.25 \\
e4 & -2.146 & 3.012 & -1.91 & 2.404 & 0.006 & -1.69 & 1.932 & 1652.33 & 1.861 & 0.138 & 0.006 & 3.15 \\
e5 & -2.047 & 2.531 & -1.51 & 2.265 & 0.45 & -0.97 & 1.098 & 1268 & 1.639 & -0.06 & 0.45 & 3.15 \\
\hline
\end{tabular}

Mz: Average; So: Standard; Sk: Skewness.

$\mathrm{mm})$, coarse sands $(0.63 \mathrm{~mm} \leq \phi<1.25 \mathrm{~mm})$, medium sands $(0.315 \mathrm{~mm} \leq \phi<$ $0.63 \mathrm{~mm})$, fine sands $(0.125 \mathrm{~mm} \leq \phi<0.315 \mathrm{~mm})$, and very fine sands $(0.063$ $\mathrm{mm} \leq \phi<0.125 \mathrm{~mm}$ ). This classification is consistent with the AFNOR standard. Table 2 and Figure 3 show the different proportions of the lake's sands. Extensive analysis shows that very coarse sands $48.34 \%$ and fine sands $29.03 \%$ are the most abundant. Coarse sands have an average proportion of $12.02 \%$. As for the medium and very fine sands, the proportions are low.

\subsection{Bottom Morphology}

Figure 4 shows the bathymetric map of Nafoun Restraint. It presents the general morphology of the lake. The main channel is elongated in an east-west direction. The reservoir has two arms in its western part. One oriented NE-SW and the other oriented NW-SE through which the waters from the Bou River tributary of Bandama arrive. The maximum depth of $5 \mathrm{~m}$ is observed near the dike and the isobaths are equidistant by $0.5 \mathrm{~m}$. The isobaths are more tightened in the central part of the main channel. In general, depths increase from upstream to the dike. The bathymetry of Lake Nafoun shows values characteristic of shallow lakes. Sedimentary inputs related to the hydrodynamics of the lake are the main causes of lake filling. However, eutrophication also contributes to the filling of the lake. Both arms have maximum depths between $2 \mathrm{~m}$ and $3 \mathrm{~m}$. The digital elevation model of the lake bottom shows $5 \mathrm{~m}$ depressions and shoals that are $1.5 \mathrm{~m}$ from 
Table 2. Percentage of granulometric classes of sands in the Nafoun reservoir.

\begin{tabular}{cccccccc}
\hline Echantillons & Long (m) & Lat (m) & VCS & CS & MS & FS & VFS \\
\hline E1 & 800,249 & $1,034,296$ & 59.57 & 14.25 & 12.48 & 13.7 & 0 \\
E2 & 800,375 & $1,033,480$ & 60.71 & 0.00 & 0.00 & 39.29 & 0.00 \\
E3 & 799,474 & $1,033,338$ & 26.09 & 17.39 & 0.00 & 56.52 & 0.00 \\
E4 & 798,532 & $1,034,265$ & 46.9 & 10.48 & 11.43 & 20 & 11.19 \\
E5 & 798,222 & $1,032,468$ & 48.44 & 17.97 & 17.97 & 15.63 & 0.00 \\
\%Total & & & 48.34 & 12.02 & 8.38 & 29.03 & 2.24 \\
\hline
\end{tabular}

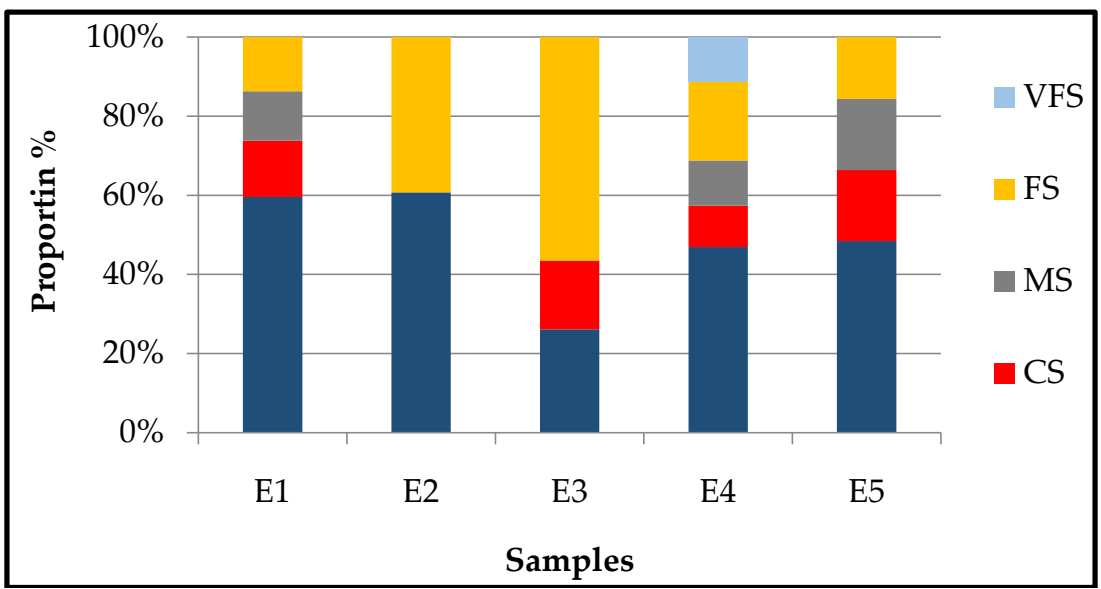

Figure 3. Percentage of the grain size fractions of the sands of the Nafoun dam (VCS: Very Coarse Sand; CS: Coarse Sand; MS: Medium Sand; FS: Fine Sand; VFS: Very Fine Sand).

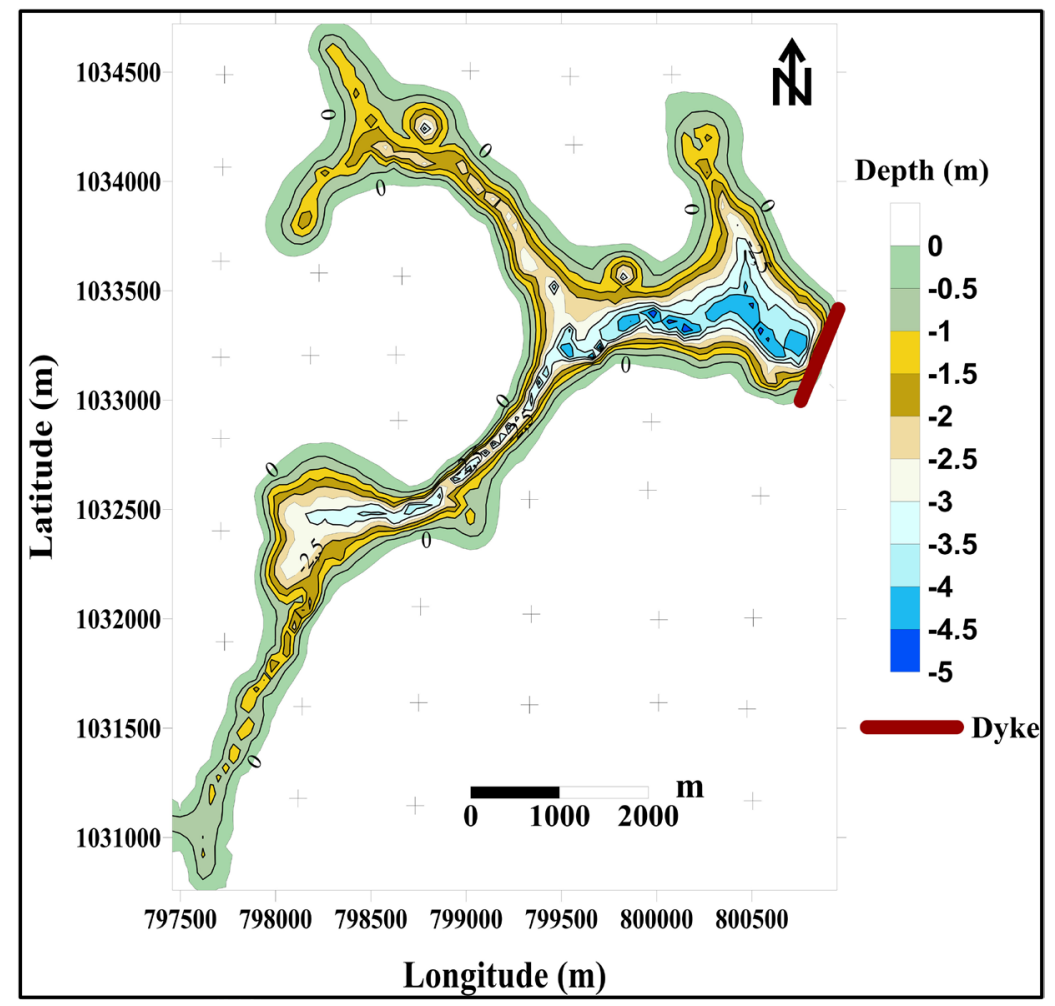

Figure 4. Bathymetric map of the Nafoun reservoir. 
the river surface (Figure 5). Depressions are caused by the increase in the river current. The shoals reflect calm hydrodynamic conditions where formations would resist erosion or would be deposition areas.

\subsection{Characteristic of the Nafoun Retainer Channel}

The morphological study of the retaining channel was based on the tracing of six (06) radial (Figure 6) including one longitudinal and five transverse. The analysis of the different profiles shows three (3) morphological types of channels: the "U" type, the "V" type and the intermediate type. The morphological profile that emerges from the $\mathrm{AB}, \mathrm{CD}$ and $\mathrm{EF}$ profiles is of the "V" type (Figure 7) more pronounced and asymmetrical with a high background. It translates a more intense erosive action. The slope is steep from the banks to the main channel. The IJ and GH profiles have a "U" shape. They are concave, flared and flattened at the base. The " $U$ " profile is an action balance profile between accumulation agents and erosion agents. But a new erosive action can resume and start the digging work again. It is said that this action is cyclical. This is sometimes referred to as a cyclical form, which means "due to the action of erosion cycles. The KL longitudinal profile has an intermediate morphology between the " $\mathrm{V}$ " type and the " $U$ " type. The morphology is sawtooth-shaped. This profile has not yet reached its form of balance which is the " $U$ " morphology. The action of accumulation agents and erosion agents does not balance. These agents allow to

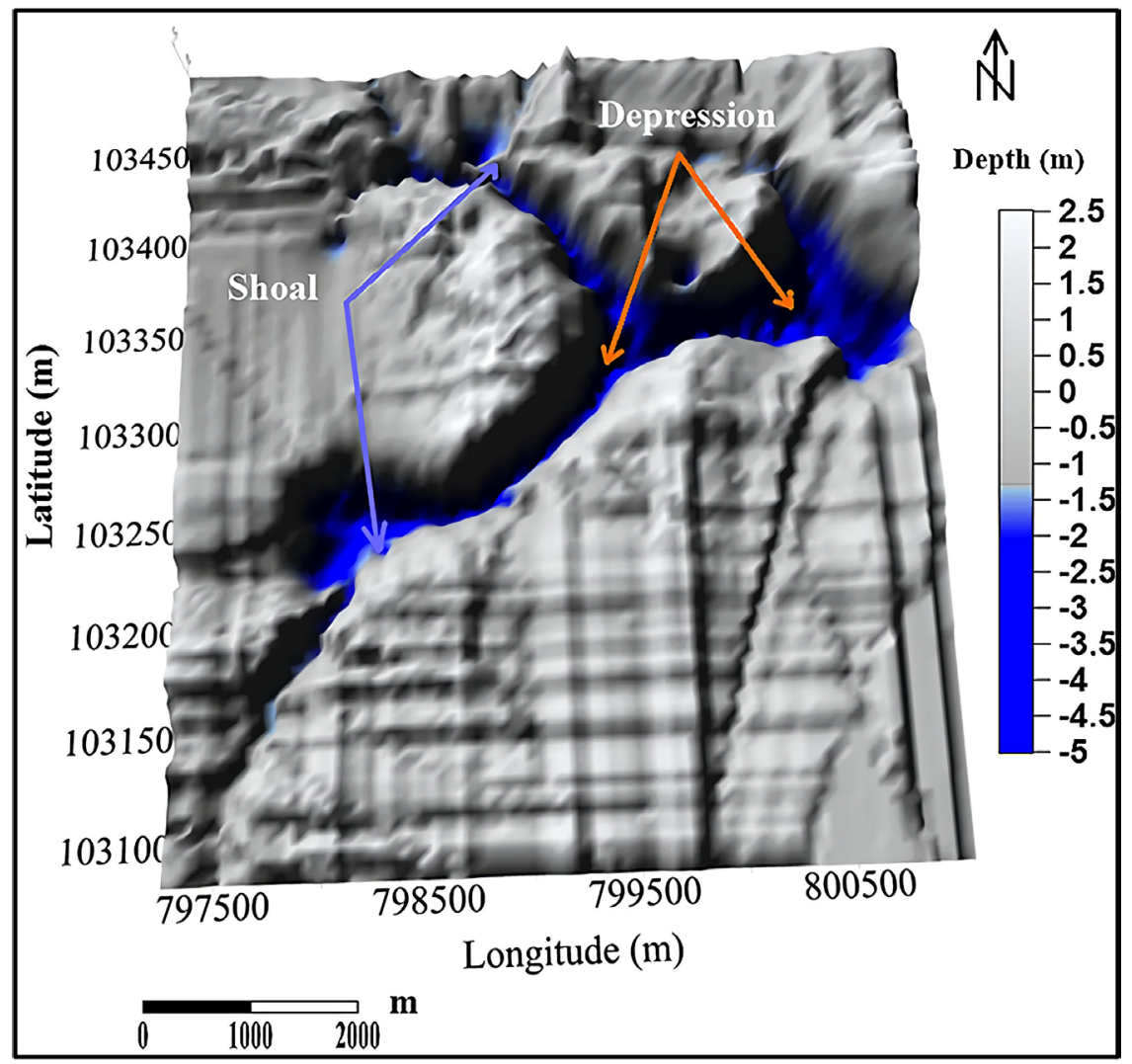

Figure 5. Digital elevation model of the lake bottom of lake Nafoun. 


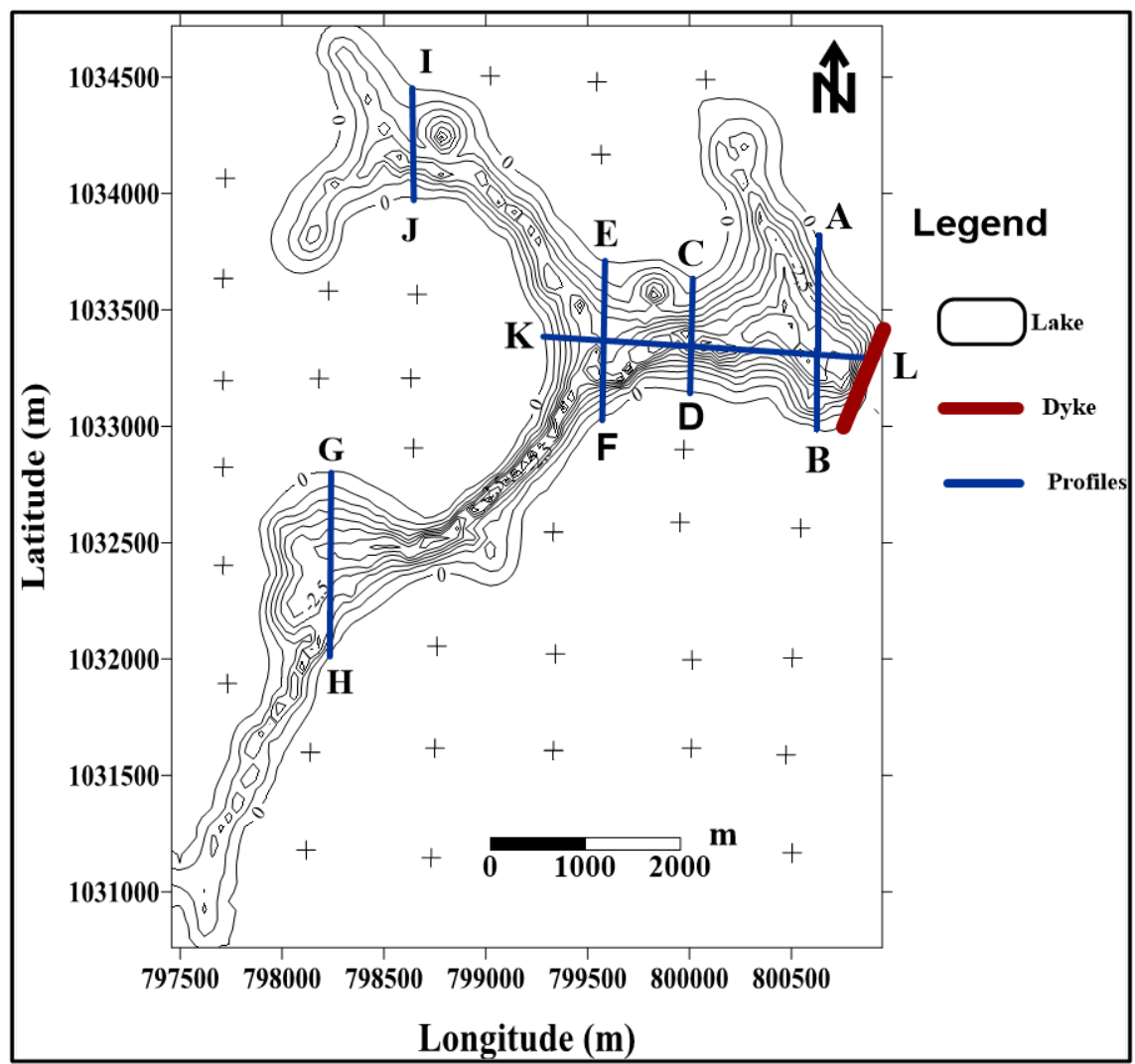

Figure 6. Bathymetric profiles at various points in Lake Nafoun.
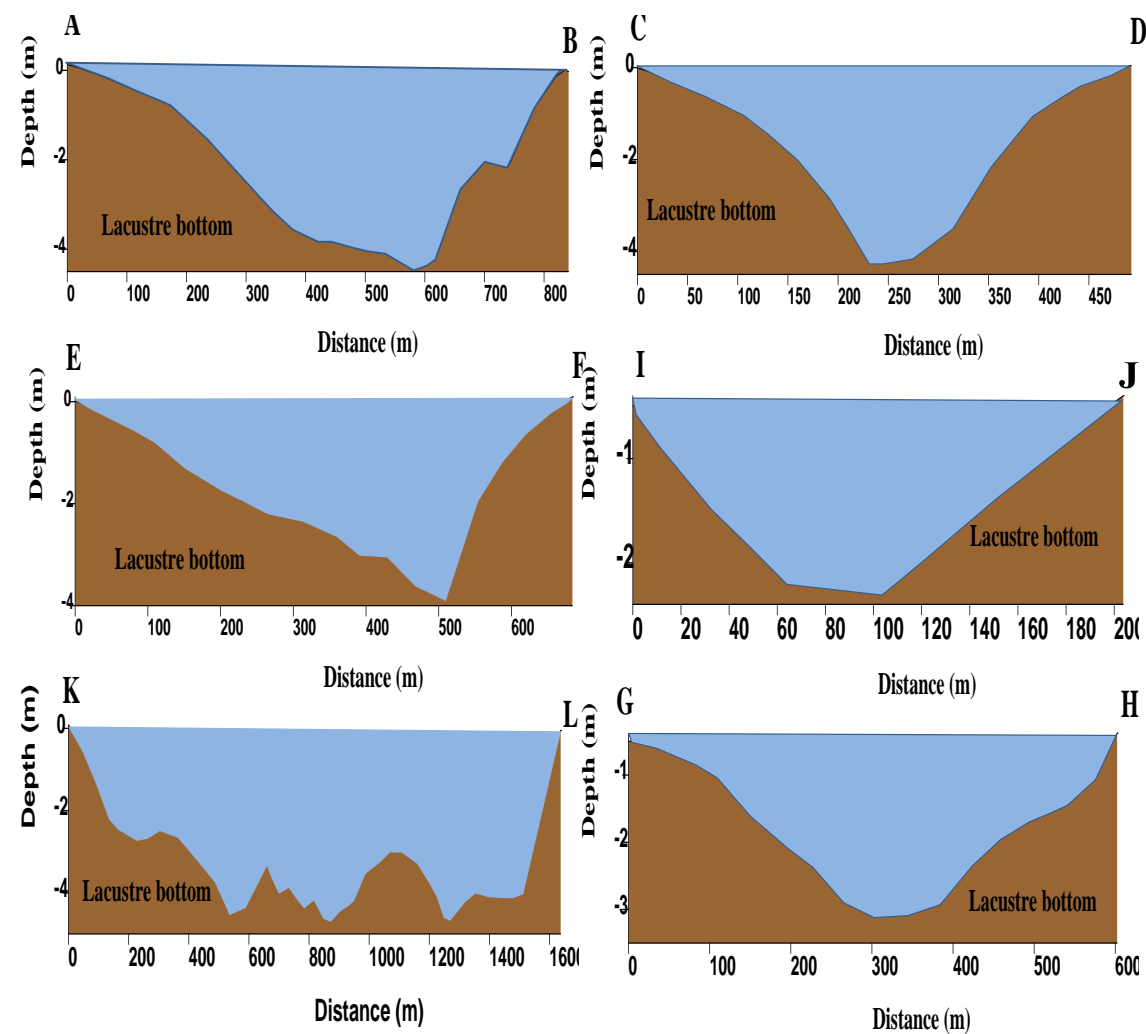

Figure 7. Bathymetric profiles of the Nafoun main channel. 
track and understand the process of evolution of an erosion profile that is characterized by the transition from the "V" profile to the "U" profile.

\section{Discussion}

The granulometric analysis of sediments collected in Nafoun Lake consists of vases that contain organic matter, fine sands, medium sands and coarse sands. The granulometric average of these sands is between $475.67 \mathrm{~m}$ and $2111 \mathrm{~m}$. These results are consistent with those found by [5] on Lake Taabo and by [22] on Lake Ayamé I. Our results differ from those obtained by [23] at the mouth of the Sassandra River. The standard difference in the lake sediments ranges from 1215 to 1861 . This indicates that the sands of the lakes are poorly classified. According to [24] sands are poorly classified if they are made of different granulometry. The Skewness (asymmetry) of Lake V sediments has from 0.37 to 0.412 . This means that in the sediments there are both fine sands and coarse sands better sorted. The sands most represented in the lake are the very coarse and fine sands. However, the presence of coarse and medium sands in the sediments is noteworthy. The predominance of very coarse sands could be explained by the distance covered by sediments in watery environments and also by the power of transport energy [24]. This assumes that the majority of coarse grains are transported over small distances. The study of the first bathymetric map of Lake Nafoun, 42 years after its impoundment, shows that it has considerable morphological irregularities. The depths of the lake vary between 0 and $5 \mathrm{~m}$. Compared to other works, the average depth obtained in Lake Nafoun $(1.58 \mathrm{~m})$ is in the same value range as those obtained by [25] in Lake Nokoué in Benin (deep-1.5 $\mathrm{m}$ ), and by [26] in Lake Digboue (deep-1 $\mathrm{m}$ ) in Côte d'Ivoire. In general, the depths decrease from upstream (dike) to down-stream. The bathymetry of Lake Nafoun shows characteristic values of shallow lakes. Sedimentary inputs related to lake hydrodynamics are the main causes of lake filling [25]. However, eutrophication also contributes to the filling of the lakes. The numerical model of elevation of the lake bottom reveals two characteristic geo-morphological aspects. These are shoals and depressions. The shoals reflect calm hydrodynamic conditions where formations would withstand erosion or would be depot areas. Depressions are caused by the increase in the river current. Our results corroborate those obtained by [5] on Lake Taaboin central of Ivory Coast, and [22] on Lake Ayamé I in the south of the country, who made the same remarks. On the other hand, our results differ from that obtained by [27] on the berries of the Ebrié lagoon which showed that the depressions recorded in the lagoon are due to anthropogenic activities such as sand dredging.

\section{Conclusion}

The study carried out on Lake Nafoun during the rainy season (July 2017 and April 2018) showed that the lake bottom is very muddy. The sedimentary flows from the ravine of the banks and the anthropic activities such as the cultivation 
of rice, tomato, eggplant, corn, sorghum, cotton, fonio at the approaches to the lake contribute to the filling of the lake bottom. Analysis of lithological facies and the granulometric of surface sediments identify vases, fine sands, middle sands and coarse sands, poorly classified. The most represented sands in the lake are the very coarse and fine sands. However, the presence of medium and coarse sands in the sediments is worth noting. The study of the first bathymetric map 42 years after its release shows that the depth oscillates between 0 and $5 \mathrm{~m}$. These depths decrease from upstream (dike) to downstream. Nevertheless, the highest depths are observed in the areas of depression. Some formations (rocks) emerge in the form of shoals on the bottom of the lakes. The results of the bathymetric maps should be used to estimate, in the long term, the lifespan of the lakes studied. The bathymetric profiles of the lake show three types of channels: " $U$," "V" and intermediate. The " $U$ " channels reflect a balance between the agents of accumulation and erosion. " $\mathrm{V}$ " channels resulting from erosion processes and intermediate-profile channels indicate an evolution of the "V" type in " $U$ " or " $U$ " in "V."

\section{Acknowledgements}

The authors of this article thank PASRES (Strategic Support Programme for Scientific Research) and CSRS (Swiss Centre for Scientific Research in Côte d'Ivoire) for agreeing to fund this research project. They also thank the Laboratory of Soil, Water and Geo-materials Sciences (LSWGS) of the University Félix Houphouët Boigny for the reception.

\section{Conflicts of Interest}

The authors declare no conflict of interest.

\section{References}

[1] Silué, P.D. (2016) Space Changes around the Natiokobadara Hydroelectric Dam in Northern Côte d'Ivoire, Ouaga University. Geography Review, 2, 112-131.

[2] Cecchi, P. (1998) From the Construction of a Multidisciplinary Object: The Little Dams of Northern Côte d'Ivoire. Natures, Science, Societies, 6, 73-83. https://doi.org/10.1016/S1240-1307(98)80015-0

[3] N'go, A. (2000) Study of Soil Erosion in the Buyo Region: Factor Analysis and Risk Assessment Test by Remote Sensing and Geographic Information Systems. Thesis of 3rd Cycle, University of Abobo-Adjamé, Abidjan, 155.

[4] Grismer, M.E. (2012) Erosion Modelling for Land Management in the Tahoe Basin, USA: Scaling from Plots to Forest Catchments. Journal of Hydrological Sciences, 57, 878-899. https://doi.org/10.1080/02626667.2012.685170

[5] Kouassi, K.L., Wognin, A.V.I., Gnagne, T., N’go, Y.A., Courivaud, J., Kassy, P., Deme, M. and Aka, K. (2007) Sand Characterization and Morphology of the Lake Bottom of the Taabo Hydroelectric Dam (Ivory Coast). The Science of Nature, 4, 93-103. https://doi.org/10.4314/scinat.v4i1.42134

[6] Kouassi, A.M., Kouame, K.F., Saley, M.B. and Biemi, J. (2013) Impacts of Climate Change on Groundwater of Crystalline and Crystallophilic Basement Aquifers in 
West Africa: The Case of the N'zi-Bandama Watershed (Ivory Coast). Larhyss Journal, 16, 121-138.

[7] Maleval, V. and Pitois, F. (2017) Hydrosedimentary Functioning and Sediment Balance of the Lake of Saint-Germain-de-Confolens (Charente, France): Geomorphological Parameters to Be Taken into Consideration in the Management of the Lake. Physio-Géo, 11, 197-227. https://doi.org/10.4000/physio-geo.5544

[8] Bessenassé, M., Kettab, A., Paquier, A., Ramez, P. and Galea, G. (2003) Digital Simulation of Sedimentation in Dam Reservoirs: Zardezas Case, Algeria. Revue des Sciences de P eau, 16, 103-122. https://doi.org/10.7202/705500ar

[9] Okacha, T., Abdelkader, M. and Med, A.T. (2002) Establishing a Geographic Information System for Monitoring and Quantifying Water Erosion: Application to the Isser Watershed (Tlemcen). Drought, 13, 175-179.

[10] Zimmerman, J., Westra, J. and Vondracek, B. (2003) Agricultural Land Use Effects on Sediment Loading and Fish Assemblages in Two Minnesota (USA) Watersheds. Environmental Management, 32, 93-105. https://doi.org/10.1007/s00267-003-2989-3

[11] Lenhart, C.F., Brooks, K.N., Heneley, D. and Magner, J.A. (2010) Spatial and Temporal Variation in Suspended Sediment, Organic Matter, and Turbidity in a Minnesota Prairie River: Implications for TMDLs. Environmental Monitoring and Assessment, 165, 435-447. https://doi.org/10.1007/s10661-009-0957-y

[12] Harnish, R.A., Sharma, R., McMichael, G.A., Langshaw, R.B. and Todd, N.P. (2014) Effect of Hydroelectric Dam Operations on the Freshwater Productivity of a Columbia River Fall Chinook Salmon Population. The Canadian Journal of Fisheries and Aquatic Sciences, 71, 602-615. https://doi.org/10.1139/cjfas-2013-0276

[13] Jourda, J.P. (2005) Methodology for the Application of Remote Sensing Techniques and Geo-Graphic Information Systems to the Study of Cracked Aquifers in West Africa. Concept of Space Hydro Technical: Cases of The Test Zones of Côte d'Ivoire. PhD Thesis, University of Cocody, Cocody, 402.

[14] Kamagaté, A., Koffi, Y.B., Kouassi, A.M., Kouakou, D.B. and Diallo, S. (2019) Impact of Climate Change on the Water Resources of Small Basins in Sub-Saharan Africa: Application to the Bandama Watershed in Tortiya (North Ivory Coast). European Scientific Journal, 15, 84. https://doi.org/10.19044/esj.2019.v15n9p84

[15] Poilecot, P., Bonfou, K., Dosso, H., Lauginie, F., N’Dri, K., Nicole, M. and Sangaré, Y. (1991) A Sudanese Savannah Ecosystem: The Comoe National Park (Ivory Coast). Technical Note 21991 NO.IVC/87/007,346.

[16] Djro, S.C. (1998) Tectono-Metamorphic Evolution of the Archean Granulitic Gneisses of the Biankouma Area. Doctorate Thesis, University of Abidjan, Abidjan, 171.

[17] Soro, N. (2002) Hydrochemistry and Isotopic Geochemistry of Groundwater of the Square Degree of Grand-Lahou and Its Surroundings (South-Western Côte d'Ivoire) Hydrological and Hydrogeological Implications. Doctoral Thesis, Natural Sciences, University of Cocody, Cocody, 272.

[18] Touré, S. (2007) Magmatic Evolution and Geodynamic Context in the Lower Proterozoic. Relationship with the Cano-Detritic Flight of Zanzan, Koun, and Tanda Attributed to the Tarkwaien of Ghana. Palaeogeographic Implications. PhD Thesis in Natural Sciences, University of Abobo Adjamé, Abidjan, 434 p.

[19] Saaidi, E. (1991) Sedimentology Treaty. Ellipses Edition, Paris, 393.

[20] Folk, R.L. and Ward, W.C. (1957) A Study in Significance of Grain Size Parameters. Journal of Sedimentary Petrology, 27, 3-26. 
https://doi.org/10.1306/74D70646-2B21-11D7-8648000102C1865D

[21] N’Guessan, Y.A., Konan, K.E., Diangone, B.E., Wango, T.E., Affian, K., Monde, S. and Aka, K. (2013) Sedimentological Characterization of Sandy Facies of Potou Lagoon (Ivory Coast Coastline). Bioterre Rev. Inter. Sci. de la terre, 13, 43-58.

[22] Meledje, H., Kouassi, K.L., N’go, Y., Kouassi, I.K.M., Savané, I. and Kouamé, A.K.A. (2014) Characterization of Sedimentary Inputs and Morphology of the Lake of the Ayamé 1 Hydroelectric Dam (South-East Côte d'Ivoire). International Journal of Biological and Chemical Sciences, 8, 1290-1307. https://doi.org/10.4314/ijbcs.v8i3.42

[23] N’Guessan, Y.A., Amani, E.M., Koffi, B.K.F., Adopo, L., Diangone, B.E., Monde, S. and Kouadio, A. (2014) Morphological and Sedimentological Characterization of the Mouth of the Sassandra River (Côte d'Ivoire). Afrique Science, 10, 277-288.

[24] Assalé, P.Y.F.A. (2013) Sedimentological, Palynological, Geochemical and Paleo Environmental Characterization of Sedimentary Formations Related to the Lagoon Fault (East of the Ivory Coast Onshore Basin). PhD Thesis, Felix Houphouët University and Boigny, Abidjan, 349.

[25] Mama, D. (2010) Methodology and Results of the Diagnosis of Eutrophication of Lake Nokoué (Benin). Doctoral Thesis, University of Limoges, Limoges, 157.

[26] Amani, M.E. (2012) Hydrodynamic Modelling Tests of the Circulation of Water Masses and Saline Dispersal in a Shallow Coastal Environment: The Digboue Lagoon (San-Pedro, Ivory Coast). PhD Thesis, Felix Houphouët University and Boigny, Abidjan, 169.

[27] Kouamé, F.A. (2017) Inflows of Morphobathymetrie to the Characterization of the Sedimentary Dynamics of Côte d'Ivoire's Lagoon-Related River Environments over the Past Four Decades (1975-2015). PhD Thesis, Félix Houphouët Boigny University, Abidjan, 209. 